\title{
Influence of urinary sodium excretion on the clinical assessment of renal tubular calcium reabsorption in hypercalcaemic man
}

\author{
SH RALSTON,* MD GARDNER, $†$ FJ DRYBURGH, $\dagger$ RA COWAN, $\dagger$ IT BOYLE,* \\ From the University Departments of *Medicine and †Biochemistry, Glasgow Royal Infirmary, Glasgow, \\ Scotland
}

SUMMARY The relation between urinary sodium excretion $\left(\mathrm{Na}_{\mathrm{E}}\right)$ and renal tubular calcium reabsorption ( $\mathrm{TmCa} / \mathrm{GFR}$ ) was assessed in patients with hypercalcaemia associated with malignancy and primary hyperparathyroidism. On acute saline loading of seven normally hydrated patients with primary hyperparathyroidism and five patients with malignancy, raised values of $\mathrm{TmCa} / \mathrm{GFR}$ were reduced to normal in most cases, in association with increases in $\mathrm{Na}_{\mathrm{E}}$. The reduction in TmCa/GFR, which occurred, may have been due to a reduction in proximal tubular calcium reabsorption associated with sodium: this would have obscured the effect of humorally mediated increases in distal tubular calcium reabsorption, which are stimulated either by parathyroid hormone or by a putative humoral mediator in hypercalcaemia of malignancy.

In patients who were normally hydrated $\mathrm{Na}_{\mathrm{E}}$ and $\mathrm{TmCa} / \mathrm{GFR}$ were not significantly correlated. When data were included from patients who were dehydrated and from those undergoing acute saline loading, significant inverse correlations between $\mathrm{Na}_{\mathrm{E}}$ and $\mathrm{TmCa} / \mathrm{GFR}$ were observed both in primary hyperparathyroidism $(r=-0.49 ; p<0.02)$ and malignancy $(r=-0.60 ; p<0.001)$.

In clinical practice changes in $\mathrm{TmCa} / \mathrm{GFR}$ associated with sodium seem to be of minor importance under normal circumstances, but they become evident at the upper and lower extremes of urinary sodium excretion. In clinical studies of renal calcium handling urinary sodium excretion must also be assessed, as interpreting TmCa/GFR data is difficult in states of excessive sodium loading or depletion.

We recently suggested that in some patients with hypercalcaemia associated with malignancy a humoral mediator is released which possesses a "PTH like" effect on renal tubular calcium reabsorption." These findings differ from those of previous workers who have generally considered that the humoral substance causing such hypercalcaemia may be distinguished from parathyroid hormone by its lack of effect on renal calcium handling. ${ }^{2-5}$ In these earlier studies renal tubular calcium reabsorption was often found to be increased before sodium repletion, but was subsequently reduced to normal, and this feature was interpreted as evidence against a renal tubular action of the putative humoral mediator that causes hypercalcaemia. ${ }^{45}$

In our study ${ }^{1}$ and in another recent study ${ }^{6}$ the renal tubular reabsorption of calcium remained increased

Accepted for publication 16 January 1986 after rehydration, suggesting that changes in renal calcium handling may indeed have been caused by the action of such a humoral mediator. The reasons for the discrepancies between these studies are at present unclear but they may relate to differences in the degree of sodium repletion. In some studies tubular calcium reabsorption was measured after sodium repletion with intravenous sodium chloride solution $0.9 \%$ (saline) 2 litres daily, ${ }^{16}$ whereas in other studies much larger quantities of saline (up to 4 litres daily) were infused, ${ }^{45}$ or rehydration procedures were not specified. $^{3}$

It is well recognised that in normocalcaemic man and in experimental animals sodium and calcium excretion are related ${ }^{7-10}$; and that variations in sodium excretion also cause variations in calcium excretion. ${ }^{10}$ In view of these factors the present study was undertaken to determine whether changes in urinary sodium excretion as a result of saline infusions affect the clinical assessment of renal tubular calcium 
reabsorption. The studies in patients with hypercalcaemia of malignancy were compared with similar data on primary hyperparathyroidism, in which a humorally mediated increase in renal tubular calcium reabsorption is known to exist. ${ }^{11} 12$

\section{Patients and methods}

\section{TWO GROUPS OF PATIENTS STUDIED \\ Primary hyperparathyroidism}

This group comprised 31 consecutive patients, diagnosed as suffering from primary hyperparathyroidism on the basis of sustained hypercalcaemia: serum calcium (mean $(\mathrm{SEM})=2.89(0.02) \mathrm{mmol} / \mathrm{l})(11.56$ $\mathrm{mg} / 100 \mathrm{ml}(0.08 \mathrm{mg} / 100 \mathrm{ml}))$ with raised or inappropriately detectable serum immunoreactive parathyroid hormone values in the absence of another identifiable cause of hypercalcaemia. In 20 of these subjects the diagnosis was subsequently confirmed by surgical exploration of the neck. One of the above patients had presented with hypercalcaemia and severe dehydration. The remaining 30 were considered to be normally hydrated on clinical and biochemical grounds at the time of study, and as such were documented to have hypercalcaemia and stable renal function (as judged by serum creatinine values) for some weeks or months before the study. Serum creatinine values were within the normal range in most cases as $81.8 \quad(5.9) \mu \mathrm{mol} / 1 \quad(0.89 \quad(0.06)$ $\mathrm{mg} / 100 \mathrm{ml}$ ) (reference range $50-130 \mu \mathrm{mol} / 1$ $(0.55-1.43 \mathrm{mg} / 100 \mathrm{ml}))$. Two subjects with renal stone disease had raised serum creatinine values, however, at 230 and $150 \mu \mathrm{mol} / 1(2.53$ and $1.65 \mathrm{mg} / 100 \mathrm{ml})$, respectively. Serum albumin values were within the reference range in most cases $(39 \cdot 2(1 \cdot 15) \mathrm{g} / \mathrm{l})$ (reference range 33-55 $\mathrm{g} / \mathrm{l})$. In seven patients from this group further studies were performed during saline infusions.

\section{HY PER CALCAEMIA OF MALIGNANCY}

This group comprised 36 patients with confirmed malignant disease who had presented with hypercalcaemia: serum calcium (3.21 (0.06) mmol/l) (12.84 $(0.24) \mathrm{mg} / 100 \mathrm{ml})$ and low or undetectable serum immunoreactive parathyroid hormone values; serum calcium values in this group were significantly higher than in primary hyperparathyroidism $(p<0.01)$. Twenty seven of these patients were studied after rehydration with $0.9 \%$ sodium chloride solution (saline) 2 litres daily, which had been routinely administered over a minimum period of 48 hours before study to correct possible sodium depletion. These patients were recorded as having stable serum creatinine values to within $5 \mu \mathrm{mol} / 1(0.05 \mathrm{mg} / 100 \mathrm{ml})$ for at least 24 hours before and after the study. Serum creatinine values were normal in most cases and com- parable with those in primary hyperparathyroidism $(81.9(4.9) \mu \mathrm{mol} / 1(0.90(0.05) \mathrm{mg} / 100 \mathrm{ml})$. Creatinine concentrations were raised in three cases $(150,150$, $190 \mu \mathrm{mol} / \mathrm{l}(1.65,1.65,2.09 \mathrm{mg} / 100 \mathrm{ml})$, respectively). Serum albumin values were generally reduced in these patients when compared with those with primary hyperparathyroidism $29.6(0.78) \mu \mathrm{mol} / \mathrm{l} \mathrm{p}<0.01$. A further four patients who presented with hypercalcaemia and dehydration were studied before receiving intravenous fluids. The remaining five patients had presented with stable hypercalcaemia and renal function, which had been documented for at least four weeks before the study. These patients were considered to be normally hydrated on clinical and biochemical grounds at the time of study, and hydration was maintained by a high oral fluid intake alone ( $>2$ litres daily). In these subjects further studies were performed during saline infusions and sub- $\nexists$ sequent administration of antiosteoclastic drugs.

\section{SALINE INFUSION STUDIES}

All patients were permitted free oral fluids and received a normal hospital diet throughout the study. In patients with primary hyperparathyroidism $\vec{\odot}$ infusions of saline were started shortly after collection of the baseline samples on day one and were sub- $D$ sequently continued for 48 hours. The rate of infusion was $500 \mathrm{ml}$ every four hours $(450 \mathrm{mmol}(450 \mathrm{mEq}) \gg$ sodium chloride daily).

In patients with hypercalcaemia of malignancy $\stackrel{\perp}{\perp}$ saline infusions were started after collection of base- $\overrightarrow{\vec{P}}$ line samples on day minus 3 . The rate of infusion was $\frac{\circ}{3}$ $500 \mathrm{ml}$ four hourly until day minus 1 , and subsequently $500 \mathrm{ml}$ six hourly until day plus 3 . On day 0 을 patients were treated with the osteoclast inhibitors; aminohydroxypropylidene diphosphonate (APD)? $15 \mathrm{mg}$ daily on days $0-6$, or mithramycin $25 \mu \mathrm{g} / \mathrm{kg}$ 윽 intravenously on day 0 and day plus 3 (one patient). It is recognised that the hypocalcaemic effect of $\delta$ these drugs principally depends on reducing bone

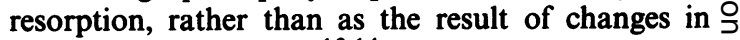
renal calcium handling. ${ }^{1314}$

\section{BIOCHEMICAL METHODS}

Biochemical analyses were performed using a multichannel autoanalyser (Technicon) on fasting blood $N$ samples and true fasting urine samples, as described $\omega$ previously. ${ }^{1}$ Total serum calcium was adjusted for 2 albumin concentration to give an "adjusted" calcium 0 value that was used subsequently throughout the $\bar{\Phi}$ study. ${ }^{15}$ Urinary sodium excretion was expressed as $\stackrel{?}{+}$ $\mathrm{Na}_{\mathrm{E}}\left(\mathrm{Na}_{\mathrm{E}}=\right.$ urine sodium, divided by urine cre- $\frac{T}{\circ}$ atinine, multiplied by serum creatinine $\mathrm{mmol} / \mathrm{l} \mathrm{GF}$

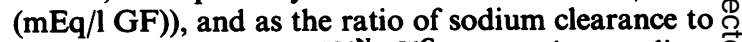
creatinine clearance $\left(\mathrm{Cl}^{\mathrm{Na}}: \mathrm{Cl}^{\mathrm{Cr}}=\right.$ urine sodium $\stackrel{\mathbb{Q}}{\varrho}$ divided by urine creatinine, multiplied by serum cre- $\bar{\sigma}$ 
atinine, divided by serum sodium). Renal tubular reabsorption of calcium was determined from fasting blood and urine samples using a nomogram to give the notional renal calcium threshold TmCa/GFR. ${ }^{16}$ Calcium excretion was also expressed as the ratio of calcium clearance to creatinine clearance $\left(\mathrm{Cl}^{\mathrm{Ca}} \mathrm{Cl}^{\mathrm{Cr}}=\right.$ urine calcium divided by urine creatinine, multiplied by serum creatinine, divided by serum calcium). Serum parathyroid hormone was measured using a radioimmunoassay as described previously. ${ }^{1}$

Statistical analysis was carried out using the Wilcoxon test for paired samples, and Spearman's rank correlation coefficient.

\section{Results}

In 30 patients with primary hyperparathyroidism who were clinically normally hydrated there was no significant correlation between $\mathrm{Na}_{E}$ and $\mathrm{TmCa} / \mathrm{GFR}$ $(r=0.27 ; p>0.05)$. When $\mathrm{Na}_{\mathrm{E}}$ and TmCa/GFR data were included from seven of these patients during saline infusions (two values in each patient (from days 1 and 2) (Fig. 1); total = 14 values) and from one additional patient who was clinically dehydrated (one value), $\mathrm{Na}_{\mathrm{E}}$ and $\mathrm{TmCa} / \mathrm{GFR}$ were significantly correlated $(r=-0.49 ; p<0.002)$ (Fig. 2).

In 27 patients with hypercalcaemia of malignancy studied during infusion of saline 2 litres daily $\mathrm{Na}_{\mathrm{E}}$ and $\mathrm{TmCa} / \mathrm{GFR}$ were not significantly correlated $(r=$ -0.16; $\mathrm{p}>0.05$ ). When $\mathrm{Na}_{\mathrm{E}}$ and $\mathrm{TmCa} / \mathrm{GFR}$ data were included from the five normally hydrated patients with hypercalcaemia associated with malignancy during saline infusions of 3 litres daily (one value in each patient from day minus 1 (Fig. 1); total = five values), and from the four patients who were clinically dehydrated (four values), there was a significant correlation $(r=-0.60 ; p<0.001)$ (Fig. 3).

In hyperparathyroid patients two values were included during saline infusions compared with only one in patients with hypercalcaemia of malignancy. The reason for this was simply because two measurements were made in hyperparathyroid patients during saline infusions (3 litres) daily compared with only one in the group with malignancy.

In the 12 patients undergoing further studies during saline infusion $\mathrm{Na}_{E}$ and $\mathrm{TmCa} / \mathrm{GFR}$ were not significantly correlated before infusion of saline was started, either in primary hyperparathyroidism $(\mathrm{n}=$ $7, r=-0.23, p>0.05)$, or in malignancy $(n=5, r$ $=-0.17 ; \mathrm{p}>0.05)$. Similarly, renal sodium clearance $\left(\mathrm{Cl}^{\mathrm{Na}}: \mathrm{Cl}^{\mathrm{Cr}}\right)$ and calcium clearance $\left(\mathrm{Cl}^{\mathrm{Ca}} \mathrm{Cl}^{\mathrm{Cr}}\right)$ did not correlate at this stage in either group $(n=7, r=$ $0.20, \mathrm{p}>0.05 ; \mathrm{n}=5, \mathrm{r}=0.15, \mathrm{p}>0.05)$.

Fig. 1 shows the response of serum calcium, $\mathrm{Na}_{E}$, and $\mathrm{TmCa} / \mathrm{GFR}$ during saline infusion in primary

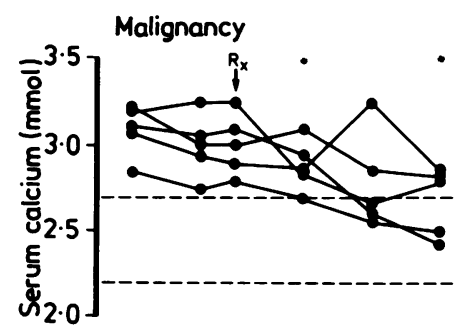

Hyperparathyroidism
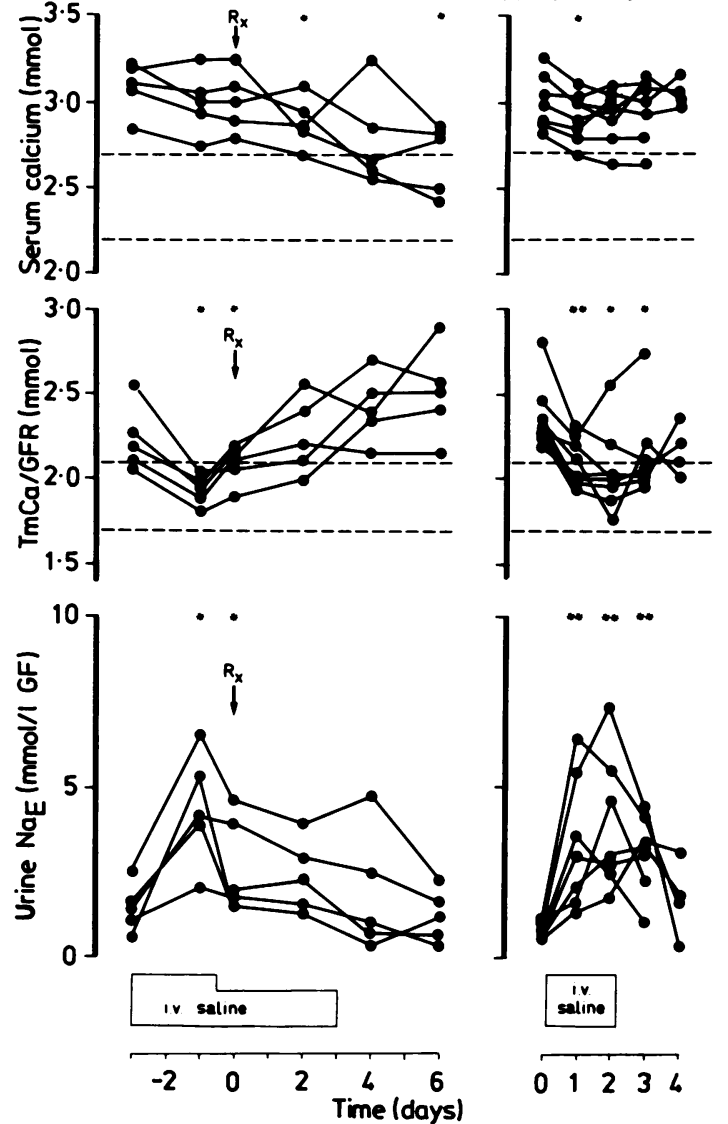

Fig. 1 Response of serum calcium urinary $\mathrm{Na}_{\mathrm{E}}$ and TmCa/GFR in normally hydrated patients undergoing saline infusion. (Significant change from initial values: ${ }^{*} p 0.05$; ${ }^{* *}$ p 0.02 .

hyperparathyroidism and malignancy. In primary hyperparathyroidism rises in $\mathrm{Na}_{\mathrm{E}}$ and falls in TmCa/GFR and serum calcium were observed during infusion of saline (days 1 and 2). These changes reversed after saline infusions were stopped and most of the above variables had returned towards their basal values by days 3 and 4 . There was a highly significant inverse correlation between $\mathrm{Na}_{E}$ and TmCa/GFR values during days $0-3$ of the study (28 pairs of observations $r=-0.72 ; p<0.001$ ) and a positive correlation between $\left(\mathrm{Cl}^{\mathrm{Na}}: \mathrm{Cl}^{\mathrm{Cr}}\right)$ and $\left(\mathrm{Cl}^{\mathrm{Ca}}: \mathrm{Cl}^{\mathrm{Cr}}\right) ;(\mathrm{r}=0.73 ; \mathrm{p}<0.001)$. (Fig. 4). Serum creatinine values were not significantly affected by the saline infusions, however, (mean (SEM) serum creatinine was $73.5 \quad(7.4) \mu \mathrm{mol} / 1 \quad(0.80 \quad(0.08)$ $\mathrm{mg} / 100 \mathrm{ml}) \nu 72.1(7.6) \mu \mathrm{mol} / 1(0.79(0.08) \mathrm{mg} / 100 \mathrm{ml})$ $v 73.5(8.1) \mu \mathrm{mol} / 1(0.80(0.09) \mathrm{mg} / 100 \mathrm{ml})$ on days 0 , 2 , and 4 , respectively. 


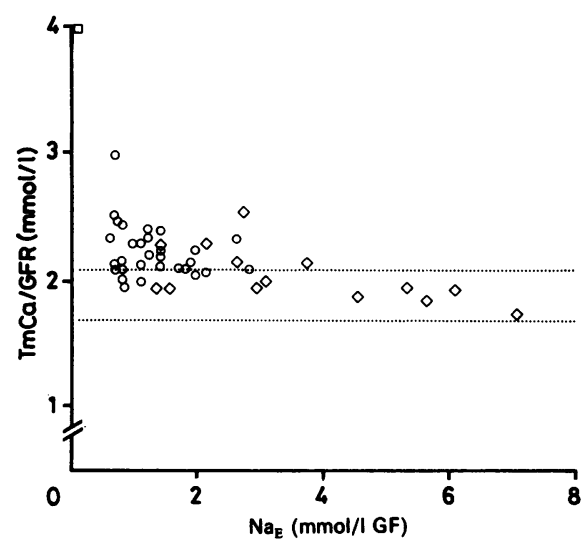

Fig. 2 Relation between urinary sodium excretion $\left(\mathrm{Na}_{E}\right)$ and renal tubular calcium reabsorption (TmCa/GFR) in patients with primary hyperparathyroidism. $\square=$ clinically dehydrated; $\bigcirc=$ normally hydrated (oral fluids); $\diamond=$ during acute saline loading (IV saline 3 litres daily).

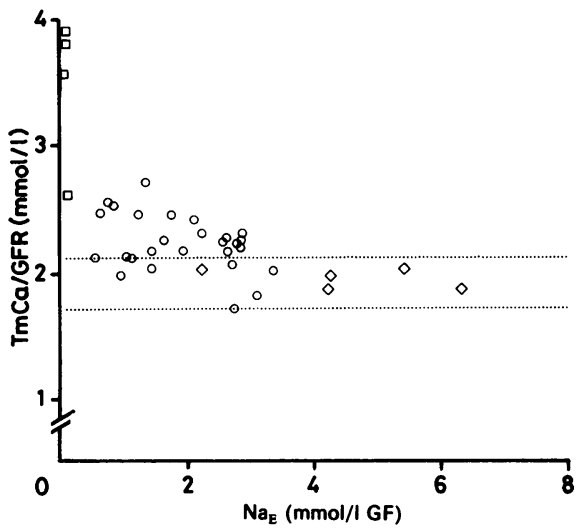

Fig. 3 Relation between urinary sodium excretion $\left(N a_{E}\right)$ and renal tubular calcium reabsorption (TmCa/GFR) in patients with hypercalcaemia of malignancy. $\square=$ clinically dehydrated; $O=$ normally hydrated (IV saline 2 litres daily); $\diamond=$ during acute saline loading (IV saline 3 litres daily).

In hypercalcaemia of malignancy a similar pattern of response was observed: significant rises in $\mathrm{Na}_{\mathbf{E}}$ and falls in $\mathrm{TmCa} / \mathrm{GFR}$ were observed on day minus 1, by which time patients had received 6 litres of saline and were continuing to receive saline infusions at the rate of $500 \mathrm{ml} / 4$ hours. On the day of antiosteoclast treatment $\mathrm{Na}_{\mathrm{E}}$ had tended to fall and $\mathrm{TmCa} / \mathrm{GFR}$ rise, as the rate of saline infusion was reduced to $500 \mathrm{ml} / 6$ hours. Following antihypercalcaemic treatment further falls in $\mathrm{Na}_{\underline{E}}$ and rises in TmCa/GFR occurred as

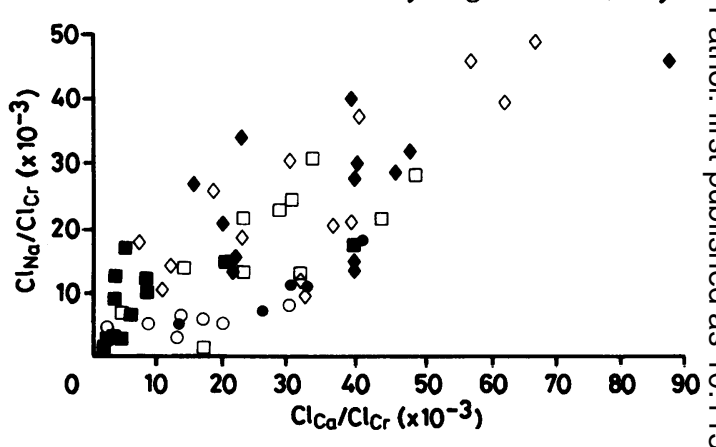

Fig. 4 Relation between renal sodium clearance $\left(\mathrm{Cl}^{\mathrm{Na}}: \mathrm{Cl}^{\mathrm{Cr}}\right)$ and renal calcium clearance $\left(\mathrm{Cl}^{\mathrm{Ca}}: \mathrm{Cl}^{\mathrm{Cr}}\right)$ during acute saline infusion studies in hypercalcaemia of malignancy and primary hyperparathyroidism. Primary Hyperparathyroidism: during IV saline $\diamond$; before IV saline $\bigcirc$; after IV saline $\square$. Malignancy: during IV saline $\diamond$; before IV saline $\bigcirc$; after anti-osteoclast therapy $\square$.

saline infusions were withdrawn. During the initial $\vec{c}$ phase of saline infusion (days minus 3 , minus 1, 0) there was a significant inverse correlation between $\mathrm{Na}_{\mathrm{E}}$ and TmCa/GFR (15 pairs of observations ( $\mathrm{r}=\varnothing_{\infty}$ $-0.70 ; p<0.01)$, and a positive correlation between? $\left(\mathrm{Cl}^{\mathrm{Na}}: \mathrm{Cl}^{\mathrm{Cr}}\right)$ and $\left(\mathrm{Cl}^{\mathrm{Ca}}: \mathrm{Cl}^{\mathrm{Cr}}(\mathrm{r}=0.77 ; \mathrm{p}<0.005)\right.$ (Fig. 4). There was, in addition, a significant inverses correlation between $\mathrm{Na}_{\mathrm{E}}$ and $\mathrm{TmCa} / \mathrm{GFR}$ and a positive correlation between $\left(\mathrm{Cl}^{\mathrm{Na}}: \mathrm{Cl}^{\mathrm{Cr}}\right)$ and $\left(\mathrm{Cl}^{\mathrm{Ca}}: \mathrm{Cl}^{\mathrm{Cr}}\right)^{\stackrel{2}{2}}$ when data were included from days plus 2 , plus 4 , and $\mathbb{\Omega}$ plus 6 , after antiosteoclast treatment (30 pairs of $\vec{F}$ observations, $r=0.74 ; p<0.001) ;\left(r=0.73 ; p<\frac{0}{3}\right.$ 0.001 ), respectively (Fig. 4). As in the case of primary hyperparathyroidism serum creatinine values did noto change significantly during the saline infusions: mean serum creatinine $=86(14.4) \mu \mathrm{mol} / 1 \quad(0.94(0.15)$ ? $\mathrm{mg} / 100 \mathrm{ml}) \nu 84(14.6) \mu \mathrm{mol} / \mathrm{l}(0.92(0.15) \mathrm{mg} / 100 \mathrm{ml})$ $v 79(15.9) \mu \mathrm{mol} / 1(0.86(0 \cdot 17) \mathrm{mg} / 100 \mathrm{ml}) v 76(9 \cdot 1)$ $\mu \mathrm{mol} / 1(0.83(0.10) \mathrm{mg} / 100 \mathrm{ml})$ on days minus 3 , minus 1,0 and plus 6 , respectively.

\section{Discussion}

We found a close correlation between urinary sodium excretion and renal tubular calcium reabsorption during acute sodium loading in normally hydrated $N$ patients with primary hyperparathyroidism and $\tilde{\omega}$ hypercalcaemia of malignancy. These findings concur with previous data: in various experimental circumeo stances proximal renal tubular reabsorption of cal- $\bar{\varnothing}$ cium has been shown to be correlated with that of ? sodium. $^{6-9}$ None the less other data have suggested 0 that, in general, proximal renal tubular calcium reabsorption is relatively stable and is a function of the filtered calcium load, ${ }^{11}$ whereas changes in overall ${ }_{\Omega} \mathrm{Q}$ tubular calcium reabsorption are determined mainlyo 
by the effects of parathyroid hormone on the distal tubule. ${ }^{12}$ Unfortunately, only the net tubular reabsorption of calcium can be determined in clinical practice. Changes in this measurement reflect the sum of changes in both proximal and distal tubular reabsorptive processes, and as such, do not distinguish between their relative contribution to net TmCa/GFR. Interestingly, there was no significant correlation between TmCa/GFR and urinary sodium excretion in normally hydrated patients with primary hyperparathyroidism who were receiving oral fluids, or in patients with hypercalcaemia of malignancy in a steady state of hydration who were receiving moderate quantities of intravenous saline ( 2 litres daily) (Figs. 2 and 3). This suggests that in these circumstances sodium independent (and possibly humoral) changes in renal tubular reabsorption were of primary importance in determining TmCa/GFR.

In clinically dehydrated patients with both malignancy and primary hyperparathyroidism $\mathrm{TmCa} /$ GFR was invariably raised, presumably as the result of increased sodium linked calcium reabsorption in the proximal tubule ${ }^{11}$ (Figs. 2 and 3). Conversely, under conditions of acute sodium loading with intravenous saline ( 3 litres daily) there was a positive correlation between the rise in urinary sodium excretion and the fall in $\mathrm{TmCa} / \mathrm{GFR}$, suggesting that decreased sodium related calcium reabsorption in the proximal tubule $^{7-10}$ was a major factor in changing the rate of renal tubular calcium reabsorption. Taken together, these findings suggest that sodium related changes in net renal tubular calcium reabsorption are of relatively minor importance under conditions of normal hydration but become evident at the upper and lower extremes of urinary sodium excretion.

In two previous studies of renal tubular calcium reabsorption in hypercalcaemia associated with malignancy, tubular calcium reabsorption was often raised before saline repletion but was generally reduced to normal afterwards. ${ }^{45}$ These findings were construed as evidence against a renal tubular action of the putative humoral mediator causing hypercalcaemia. Our data suggest that such conclusions are invalid, however, as although reductions in $\mathrm{TmCa} / \mathrm{GFR}$ were observed during saline infusions in our patients with hypercalcaemia of malignancy, they were also observed in primary hyperparathyroidism, a condition in which a parathyroid hormone mediated rise in renal tubular calcium handling is known to exist. ${ }^{1112}$ It is apparent from these data that even moderate degrees of sodium loading can cause clinically important reductions in net renal tubular calcium reabsorption, even in the presence of a humorally mediated increase in distal tubular reabsorption.

It is difficult to put a precise value on the amount of urinary sodium excretion that would be expected to cause clinically important changes in TmCa/GFR from our data. Such effects, however, seem to predominate at the upper and lower extremes of urinary sodium excretion $\left(\mathrm{Na}_{\mathbf{E}}>5 \mathrm{mmol} / \mathrm{l}(\mathrm{MEq} / \mathrm{l}) \mathrm{GF}: \mathrm{Na}_{\mathbf{E}}\right.$ $<0.10 \mathrm{mmol} / 1(\mathrm{MEq} / \mathrm{l}) \mathrm{GF})$. In the studies of hypercalcaemia associated with malignancy cited above ${ }^{4} 5$ renal tubular calcium reabsorption was generally assessed at the values of sodium excretion, which were raised, when compared with our normally hydrated patients; thus in one study median $\mathrm{Na}_{E}$ was $4.9 \mathrm{mmol} / \mathrm{l}: \mathrm{GF}$ (MEq/lGF) and the other $5.8 \mathrm{mmol} / \mathrm{l}: \mathrm{GF}(\mathrm{MEq} / \mathrm{l} \mathrm{GF})$; this suggests that the "normal" TmCa/GFR values observed in some cases may, in fact, have largely been the result of a sodium related reduction in proximal tubular calcium reabsorption and as such did not exclude a concomitant increase in humorally mediated distal tubular calcium reabsorption.

From the clinician's point of view assessment of TmCa/GFR under conditions of normal sodium balance is desirable in hypercalcaemic disorders for diagnostic and therapeutic purposes. ${ }^{17}$ Our data re-emphasise the importance of measuring sodium excretion in any investigation of renal tubular calcium reabsorption. ${ }^{10}$ Moreover, we suggest that caution must be exercised in the interpretation of renal tubular calcium reabsorption data in patients who are excessively loaded with or depleted of sodium.

We thank Professor OLM Bijvoet for supplying the amino hydroxypropylidene diphosphonate.

\section{References}

${ }^{1}$ Ralston SH, Fogelman I, Gardner MD, Dryburgh FJ, Cowan RA, Boyle IT. Hypercalcaemia of malignancy: evidence for a nonPTH humoral agent with an effect on renal handling. Clin Sci 1984;66:187-91.

${ }^{2}$ Mundy GR, Ibbotson KJ, D'Souza JM, Simpson EL, Jacobs JW, Martin TJ. The hypercalcaemia of cancer. $N$ Engl J Med 1984;310:1718-27.

${ }^{3}$ Stewart AF, Horst R, Deftos LJ, Cadman EC, Lang R, Broadus AE. Biochemical evaluation of patients with cancer associated hypercalcaemia. $N$ Engl J Med 1980;303:1377-83.

${ }^{4}$ Sleeboom HP, Van Oosterom AT, Bijvoet OLM, Gleed JH, O'Riordan JLH. Comparison of intravenous (3-amino-1hydroxypropylidene-1-1-bisphosphonate) and volume repletion in tumour associated hypercalcaemia. Lancet 1984;i:239-43.

${ }^{5}$ Hosking DJ, Cowley A, Bucknall CA. Rehydration in the treatment of severe hypercalcaemia. $Q J \mathrm{Med} 1981 ; 200: 473-81$.

${ }^{6}$ Hosking DJ, Gilson D. Comparison of the renal and skeletal actions of calcitonin in the treatment of severe hypercalcaemia. $Q J$ Med 1984;211:359-68.

${ }^{7}$ Walser M. Calcium clearance as a function of sodium clearance in the dog. Am J Physiol 1961;200:1099-104.

${ }^{8}$ Kleeman CR, Bohannan J, Bernstein D, Ling S, Maxwell MH. Effect of variations in sodium intake on calcium excretion on normal humans. Proc Soc Exp Biol Med 1964;115:29-32. 
${ }^{9}$ Lassiter WE, Gottschalk CW, Mylle M. Micropuncture study of renal tubular reabsorption of calcium in normal rodents. Am J Physiol 1963;204:771-5.

${ }^{10}$ Silver J, Friedlander MM, Rubinger D, Popoutzer MM. Sodium dependent idiopathic hypercalciuria in renal stone formation. Lancet 1983;ii:484-6.

${ }^{11}$ Bijvoet OLM. The kidney in calcium and phosphate metabolism. In: Avioli LV, Krane SM, eds. Metabolic bone disease. Vol. 1. New York: Academic Press, 1977:49-140.

12 Peacock M, Robertson WG, Nordin BEC. Relation between serum and urinary calcium with particular reference to parathyroid activity. Lancet $1969 ; \mathrm{i}: 384-6$.

${ }^{13}$ van Breukelen FJM, Bijvoet OLM, Frijlink WB, Sleeboom HP, Mulder H, van Oosterom AT. Efficacy of aminohydroxypropylidene bisphosphonate in hypercalcaemia: observations on regulation of serum calcium. Calcif Tissue Int 1982;34:321-7.
${ }^{14}$ Kiang DT, Loken MK, Kennedy BJ. Mechanism of the hypocalcaemic effect of mithramycin. Journal of Clinical Endocrinology and Metabolism 1979;48:341-4.

${ }^{15}$ Gardner MD, Dryburgh FJ, Fyffe JA, Jenkins AS. Predictive value of derived calcium figures based on the measurement of ionised calcium. Ann Clin Biochem 1981;18:106-9.

${ }^{16}$ Nordin BEC. In: Nordin BEC, ed. Calcium, phosphate and magnesium metabolism. Edinburgh: Churchill Livingstone, 1976.

${ }^{17}$ Ralston SH, Gardner MD, Boyle IT. Raised renal tubular calcium reabsorption predicts poor response to osteoclast inhibitors in cancer associated hypercalcaemia. Scot Med J 1985;30:126.

Requests for reprints to: $\mathrm{Dr}$ SH Ralston, University Department of Medicine, Royal Infirmary, 10 Alexandra Parade, Glasgow G31 2ER, Scotland. 